\title{
ANATOMY OF A GOVERNANCE TRANSFORMATION: THE CASE OF DAIMLER-BENZ
}

\author{
DENNIS E. LOGUE* AND JAMES K. SEWARD**
}

I

\section{INTRODUCTION}

In 1996, the McKinsey Global Institute released a study posing the following question: If savings rates in Germany and Japan have been so high for a long time relative to those in the United States, why have their per capita gross domestic products ("GDP") not grown to be much greater than that of the

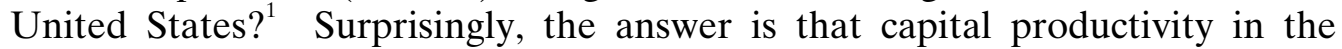
United States has been significantly greater than capital productivity in Germany and Japan. Indeed, over the period of 1974 to 1993, the study found that the real after-tax rate of return to all investment in the corporate sector averaged $9.1 \%$ per annum in the United States, but only $7.4 \%$ per annum in Germany and $7.1 \%$ per annum in Japan. ${ }^{2}$

Capital has been invested much more efficiently in the United States than in Germany or Japan. More detailed analysis indicates that there is much overinvestment in Germany and Japan and, hence, unutilized capacity. In particular, Germany has witnessed much "gold-plating" of capital investment, that is, the installation of equipment that is much better-and more expensive-than is required. ${ }^{3}$ Moreover, there has been no offsetting improvement in labor productivity. Consequently, despite heavy investment, living standards have not improved significantly in Germany or Japan relative to those in the United States.

Why is there inefficient investment in Germany and Japan? It is not caused by lack of investment tools because managers in both countries have access to the same tools that U.S. managers use to identify productive investments and to

Copyright $@ 2000$ by Dennis E. Logue \& James K. Seward

This article is also available at http://www.law.duke.edu/journals/62LCPLogue.

* Stephen Roth Professor of Management, Amos Tuck School, Dartmouth College.

** Associate Professor of Finance, School of Business, University of Wisconsin-Madison.

We are grateful to James Hodder, Paul MacAvoy, and particularly to the special editors of this issue, Michael Bradley, Cindy Schipanni, Anant Sundaram, and James Walsh for many helpful comments that guided the development of this article.

1. See McKinsey Global Inst., CAPITAl Productivity 2 (1996).

2. See id. at 1 .

3. See id. "[F]or many German firms ineffective investment planning lowered capacity utilization, and 'gold-plating' and over engineering were common. For example, the phone cables of Deutsche Telecom must be able to withstand being run over by a tank." Id. at 3. 
operate them efficiently. The over-investment must be caused by German and Japanese managers' decisions leading to excessive investment relative to the standards of economic efficiency. This article suggests that there is inefficiency by design, induced by the goals and systems of corporate governance in these countries.

An article in this volume by Bradley et al. provides some theoretical insight into this issue. ${ }^{4}$ The authors categorize corporate governance systems as either "contractarian" or "communitarian." At the risk of oversimplification, a contractarian system encourages firms to focus on shareholder value. A communitarian system, in contrast, responds to all "stakeholders:" creditors, employees, customers, and communities where corporate operations are located and, finally, stockholders. The concern for a much broader constituency may lead to over-investment, often to the detriment of shareholders. Over-investment helps creditors, particularly when firms diversify because of co-insurance effects, and it helps employees because diversifying investment creates jobs and improves job security. Furthermore, it aids customers by creating more consumer choice, and it helps the community by broadening the tax base.

Approaching the governance question from another perspective, La Porta et al. find that countries without common law traditions and strong shareholder protections do not have well-developed external capital markets. ${ }^{5}$ Not only does this mean that companies must look to the banking sector for financing, but it also means that neither activist shareholders nor the market is imposing much external discipline on companies for corporate control. The result is that banks control corporate financing and investment decisions, and, in their positions primarily as lenders and secondarily as equity holders, they encourage corporations to invest up to inefficient levels so long as credit quality remains sufficiently high.

Though many scholars believe the two systems of corporate governancecontractarian and communitarian-can co-exist in a globally competitive world, ${ }^{6}$ Bradley et al. argue otherwise. ${ }^{7}$ They contend that the forces of globalization and worldwide competition for capital will eventually force corporations-and the countries in which they are domiciled-to shift to the contractarian paradigm to set corporate goals and implement governance systems. Risk-taking capital providers must receive adequate rewards for providing financing to global competitors.

In this article, we provide empirical evidence using a detailed case study to support the Bradley et al. hypothesis that the trend toward the contractarian

4. See Michael Bradley et al., The Purposes and Accountability of the Corporation in Contemporary Society: Corporate Governance at a Crossroads, 62 LAW \& CONTEMP. PROBS. 9 (Summer 1999). (1997).

5. See Rafael La Porta et al., Legal Determinants of External Finance, 52 J. FIN. 1131, 1137-50

6. See, e.g., Mark J. Roe, German “Populism” and the Large Public Corporation, 14 InT'L REV. L. \& ECON. 187-202 (1994); Andrei Shleiffer \& Robert Vishny, A Survey of Corporate Governance, 52 J. FIN. 737, 769 (1997).

7. See Bradley et al., supra note 4 , at 85-86. 
model is actually occurring. In the case study, we examine the evolutionary transformation in the corporate governance structure of Daimler-Benz A.G., the largest German industrial company. ${ }^{8}$

An examination of Daimler-Benz, now DaimlerChrysler, is noteworthy for several reasons. First, the automotive industry is acutely affected by each of the five major force changes identified by Bradley et al. Because these changes are predicted to induce the need for change in corporate governance systems, the industry itself represents a natural starting point to examine the impact of these environmental changes on the corporate governance practices of multinational enterprises.

Second, capital acquisition is an important source for investment in the automotive industry. Because Daimler-Benz's recent capital needs exceeded its internally generated funds and available domestic sources of funds, it is possible to examine the relationship between the need for external funds, the necessity of tapping global sources of capital, and the transformation of a firm's corporate governance structure.

Third, the announcement and completion of the merger agreement between Daimler-Benz and Chrysler Corporation provides an opportunity to examine the impact of a significant corporate event on the melding of somewhat distinct corporate governance systems. In particular, the combination of a firm historically managed under the contractarian model of corporate governanceChrysler-and a firm historically managed under the communitarian model of corporate governance-Daimler-Benz-provides an interesting, natural experiment in which to examine the marginal impact of a corporate combination on distinct corporate governance structures.

Overall, the evidence supports the view that, over the last several years, Daimler-Benz has taken numerous steps toward prioritizing shareholder value more intensely than ever before. Moreover, there exists virtually no evidence to suggest that the company will deviate from this focus in the future. The evidence supports the hypothesis that even before the decision to acquire Chrysler, Daimler-Benz shifted toward a contractarian governance system as a matter of survival in a world of intense global competition in financial and product markets.

The remainder of the article is organized as follows. Part II offers a brief overview of the German corporate governance system in which Daimler-Benz operates. ${ }^{9}$ Part III enumerates the steps taken by Daimler-Benz to signal to the

8. When this article was first drafted, Daimler-Benz and Chrysler had not yet publicly announced their merger talks. Since then, Daimler-Benz has merged with Chrysler, forming DaimlerChrysler. We have chosen to retain the focus on Daimler-Benz because its actions toward becoming a more shareholder-focused company began before its public involvement with Chrysler. Its merger with Chrysler simply continued a well-established trend.

9. There are many fine, detailed discussions of German corporate governance. Bradley et al., supra note 4, provide an excellent analysis. For discussions that do not foretell the demise of the German corporate governance system, see Jonathan R. Macey \& Geoffrey P. Miller, Corporate Governance and Commercial Banking: A Comparative Examination of Germany, Japan, and the United States, 
world that its focus has changed from delicately balancing the interests of its many constituencies to paying increased attention to shareholder value creation. Part III also considers the results of Daimler-Benz's actions. The article concludes by asking whether the transformation is more likely to be temporary or permanent. Will DaimlerChrysler continue its pursuit of shareholder value or will it revert to its communitarian ways?

II

\section{GERMAN CORPORATE GOVERNANCE AND DAIMLER-BENZ}

Banks dominate German financial markets and the financial structure of most large German firms. ${ }^{10}$ Daimler-Benz is no exception.

In the late 1980s, the top five shareholders in Daimler-Benz were banks, which controlled $78.39 \%$ of the voting stock. ${ }^{11}$ Deutsche Bank alone owned nearly thirty percent and controlled more than forty-one percent of the voting stock in 1990. ${ }^{12}$ Just before Daimler-Benz listed its American Depository Receipts ("ADRs") on the New York Stock Exchange ("NYSE") in 1993, Deutsche Bank owned roughly twenty-eight percent of Daimler-Benz stock. ${ }^{13}$ By June 1998, it owned approximately twenty-two percent as a result of its own stock sales and new shares issued by Daimler-Benz. ${ }^{14}$ Although Deutsche Bank still retains a large fraction of ownership, it has reduced its ownership by a significant margin. Currently, the second largest owner of Daimler-Benz is the government of Kuwait, with thirteen percent of the stock. ${ }^{15}$

Large German companies have two governing boards: the supervisory board and the management board. The supervisory board is composed of directors and representatives of various labor groups, including "white collar" employees. Half of the board is elected by shareholders, and the other half is elected by employees. The chairman has two votes to break ties. ${ }^{16}$ The management board is composed of the corporation's top managers. It is responsible for the day-to-day management of the firm and reports to the supervisory board. ${ }^{17}$

The supervisory board of Daimler-Benz has twenty members. The chairman of Daimler-Benz's supervisory board, Hilmar Kopper, also happens to be the chairman of Deutsche Bank's management board. Of the nine other share-

48 StAn. L. ReV. 73, 73-109 (1995); Mark Roe, Some Differences in the Corporate Structure in Germany, Japan, and the United States, 102 YALE L.J. 1927, 1927-2003 (1993).

10. See Roe, supra note 9, at 1937-47.

11. See id. at 1938. Voting power in Germany often resides with the custodians of the securities.

These five banks did not own $78.1 \%$ of the stock; they only controlled this percentage of votes.

12. See id. at $1938,1998$.

13. See David Waller, Deutsche Bank Signals Rethink of $28 \%$ in Daimler Benz, FIN. TIMES, Mar. 18,1993 , at 25 .

14. See Daimler-Benz, SEC Form 20-F, at 31 (Apr. 16, 1997).

15. See id.

16. See Daimler-Benz, SEC Form 20-F, at 61 (Apr. 8, 1998).

17. See id. at 63 . 
holder-elected directors, three are top officials at Germany's leading banks. Banks have played a significant role in the governance of Daimler-Benz and are still very influential.

The key functions of the supervisory board are to appoint the management board and to approve major corporate decisions, including corporate strategy. Evidence gathered by Steven Kaplan indicates that German supervisory boards are responsive to poor stock returns and earnings losses. ${ }^{18}$ Top managers are fired for poor financial performance but not for failing to achieve growth. It appears that only a threat to the safety of the large bank debt carried by German firms can be cause for termination. As long as the company remains financially secure, managers seem to have little reason to worry about job security.

Edzard Reuter, chairman of Daimler-Benz, was replaced in 1995 when Daimler-Benz's stock price was still below its 1986 price. The company was experiencing serious losses, and it became clear that the company was in dire need of restructuring as a consequence of excessive diversification. ${ }^{19}$ Ironically, much of the diversification Daimler-Benz had achieved was motivated and financed by the banks because bank loans can be made safer if firms diversify, even though shareholders may lose from this form of investment. ${ }^{20}$

It is notable that not only is corporate governance dominated by bankers, but German corporate finance is also dominated by banks. ${ }^{21}$ Roughly speaking, for every dollar a German company obtains from external capital markets, it obtains $\$ 4.20$ from banks. In contrast, an American firm borrows only eightyfive cents from banks for every dollar it raises in capital markets. ${ }^{22}$

This bank dominance effectively means that under the traditional system of corporate governance in Germany, external capital markets exert little discipline. This lack of discipline may account for the over-investment that led to the low investment returns noted earlier. So long as investments produce returns sufficient to meet debt service obligations, lenders tolerate excessive investment because the loser is the shareholder, the residual claimant. Similarly, labor tolerates excessive investment-labor representatives comprise one-half of a German firm's supervisory board-because it creates jobs and the loss is, once again, borne by the shareholder. In the Daimler-Benz case, forty percent of the shareholder representatives to the supervisory board were and are bankers who also lend to Daimler-Benz. ${ }^{23}$ Accordingly, the calculation they might make when Daimler-Benz borrows to over-invest is whether their profits on the loans offset the opportunity costs on their stock holdings.

18. See Steven N. Kaplan, Top Executives, Turnover, and Firm Performance in Germany, 10 J.L. ECON. \& ORG. 142, 148-55 (1994).

19. See John Templeman et al., Revolution at Daimler, BUS. WK., Feb. 5, 1996, at 56, 56-57.

20. Daimler-Benz had borrowed so much that its equity equaled only about $20 \%$ of total assets.

21. See Macey \& Miller, supra note 9 , at 89.

22. See id.

23. See Daimler-Benz, supra note 16, at 62. Ten of the board members are bankers who lend to Daimler-Benz. See Roe, supra note 9, at 1998. 
Finally, German accounting systems can obscure the true picture of a company's financial health. ${ }^{24}$ This alone can cause equity investors to avoid the stock and may, in fact, penalize such companies with a much higher cost of equity than they would enjoy with greater transparency.

When Daimler-Benz agreed to produce a set of books consistent with U.S. Generally Accepted Accounting Practices ("GAAP") before listing on the NYSE, huge reserve accounts were uncovered, and Deutsche Marks ("DM") 4 billion in pension provisions were reclassified as extraordinary profit for $1992 .{ }^{25}$ To further illustrate, Daimler-Benz's 1995 Annual Report shows 1993 net income of DM 615 million using German GAAP but a loss of DM 1,839 million using U.S. GAAP. ${ }^{26}$ United States GAAP are more informative because there are fewer reserve accounts in which to hide profits in good years and on which to draw upon in bad years to smooth reported income. ${ }^{27}$ This increased transparency alone is beneficial to shareholders and will tend to make the company more responsive to their concerns. Clearer financial statements present shareholders with a better picture of what is wrong with the company.

III

\section{THE TRANSFORMATION OF DAIMLER-BENZ}

\section{A. Overview}

Daimler-Benz was-and DaimlerChrysler is-Germany's largest industrial corporation. It has four main product lines: automobiles; aeroplanes and aerospace; rail systems, diesels, and electrical components; and services, which are mostly financial in nature. Its former chairman of the management board, Edzard Reuter, spent much of his time diversifying the corporation. His successor has focused on its corporate businesses so far; indeed, within two months of Reuter's retirement from the management board in April 1995, the company began the restructuring process. ${ }^{28}$ Partly as a result of these efforts, the market value of Daimler-Benz stock has increased from $\$ 24.7$ billion at the beginning of 1995 to more than fifty billion dollars by the end of June $1998 .^{29}$

24. See Bradley et al., supra note 4, at 70; David Duffy \& Luchlan Murray, The Wooing of American Investors, WALL ST. J., Feb. 25, 1994, at A14.

25. See Wendy Cooper, Discovering the Foreign Investor, InSTITUTIONAL INVESTOR, July 1993, at 81, 81-84.

26. See DAimler-BenZ, 1995 Annual Report 5 (1996).

27. For an excellent discussion of how German and U.S. accounting systems can be reconciled, see Salomon Smith Barney, Gyrus-The Search for Value in Global Autos, GlobAL EQUiTy RES. Automotive, May 29, 1998, at 83, 83-109.

28. See Daimler in Difficulty, Fin. Times, Aug. 8, 1995, at 13; Wolfgang Muncha \& Peter Norman, Planes, Trains, and Automobiles, FIN. TIMES, Nov. 7, 1995, at 19.

29. Market values are computed from Daimler-Benz $A G$, in STANDARD \& POOR'S STOCK REPORTS (Jan. 11, 1995) and Chrysler Corp., in STANDARD \& POOR'S STOCK REPORTS (Aug. 15, 1998). 
On October 5, 1993, Daimler-Benz listed its shares on the NYSE to gain access to the global capital markets. The German public securities market is extremely small relative to its GDP. At the end of 1995, the market capitalization of German exchange-traded stock was only $\$ 547$ billion, or less than forty percent of its GDP. ${ }^{30}$ In contrast, the market capitalization of the U.S. market was approximately $\$ 6.9$ trillion, or nearly sixty percent of its GDP. ${ }^{31}$ Thus, DaimlerBenz gained entry into a much more resilient market that would provide the company greater financial flexibility than would the German market. Financial flexibility may be necessary to compete effectively in the product markets.

It is unclear whether Daimler-Benz decided to make this move on its own, with perhaps some prodding from its principal shareholder, Deutsche Bank, or whether Deutsche Bank insisted on the NYSE listing and perhaps improved performance by Daimler-Benz to help solve some of the bank's own financial performance problems. Two facts are germane. First, Deutsche Bank had been experiencing return on equity of approximately eight percent, while Citibank and other global bankers were enjoying returns on equity of roughly twenty percent. ${ }^{32}$ Deutsche Bank was far from being a high-performance bank. Perhaps it urged Daimler-Benz to improve both Daimler-Benz's and the bank's performances, thereby enhancing its own ability to attract global capital. Second, new Daimler-Benz shares were not sold at the time of the listing. Rather, existing shares were bought by the ADR custodian and were converted into ADRs. However, in January 1994, Deutsche Bank sold approximately $\$ 700$ million of Daimler-Benz shares in an underwritten secondary offering in the United States. ${ }^{33}$ Thus, the first beneficiary of Daimler-Benz's newly discovered access to global capital was Deutsche Bank itself. Daimler-Benz raised nearly \$200 million through a rights offering in June $1994 .^{34}$ Since then, Daimler-Benz has raised many hundreds of millions more in the United States.

Deutsche Bank's own well-being has been beneficially influenced not only by Daimler-Benz's access to global capital, but also by its increased commitment to shareholder value creation. It is one thing to raise capital in global markets; it is quite another to raise it on favorable terms. To do so, DaimlerBenz had to make a credible commitment to the global investment community that it would reform itself by adopting the contractarian model of governance, the system more closely associated with shareholder value creation.

Since its listing on the NYSE, Daimler-Benz has taken many positive steps toward altering its regard for shareholder value. In fact, in its 1997 Annual Report, Daimler-Benz openly asserted its commitment to generate returns in every business unit demanded by international standards, to achieve a leading position in every market it serves, to seek opportunities to expand its presence

\footnotetext{
30. See RichARD LEVICH, INTERNATIONAL FinANCIAL MARKETS 528 (1998).

31. See id.

32. See Templeman et al., supra note 19, at 56.

33. See Daimler-Benz $A G$, in STANDARD \& POOR's STOCK REPORTS (Mar. 18, 1994).

34. See Daimler-Benz $A G$, in STANDARd \& POOR's StOck RePORTS (Jan. 11, 1995).
} 
in foreign markets with a special emphasis on Asia, and to grow businesses in which it has technological and managerial expertise. ${ }^{35}$ These corporate goals are ones that the most extreme shareholder value creation organization would be proud to advertise. The list, quite symbolically, makes no mention of happy employees or a satisfied state.

More concretely, Daimler-Benz has taken a number of steps, including a voluntary restructuring, both to enhance shareholder wealth and demonstrate the sincerity of the firm's new-found commitment to shareholders.

\section{B. Financial Performance}

Table 1 provides a financial overview of Daimler-Benz's performance from 1986 to 1997 . There are several notable features. First, return on equity slipped dramatically in the early 1990s. Admittedly, the very large positive and negative numbers are, in part, a consequence of extraordinary accounting items. However, the pattern is similar with and without the extraordinary items. Second, net worth relative to total assets shows heavy use of financial leverage, though this is not high by auto company standards. Given that Daimler-Benz's market value has averaged a little more than two times its book value-somewhat higher than most other auto companies-its leverage is considerably less than it appears to be. Moreover, as the data in Panels A and B of Table A1 suggest, Daimler-Benz's financial leverage-even on a book value basis - is generally lower than that of its automotive peers. Third, as Table 1 reveals, Daimler-Benz's employment has shrunk significantly in recent years. From a high of nearly 380,000 employees in 1991, Daimler-Benz decreased to only 300,000 employees by the end of 1997 . Moreover, most of this reduction occurred in Germany, where the number of employees dropped by more than 80,000 over the same period. Finally, Daimler-Benz's market capitalization reached $\$ 26.9$ billion by the end of 1986 . Despite the net sale of additional shares, market capitalization did not exceed this value again until 1996. Overall, the evidence suggests that financial performance began to improve after two important events in the early 1990s - the listing of Daimler-Benz shares on the NYSE and the replacement of the "communitarian" incumbent Chief Executive Officer ("CEO") with a new "contractarian" CEO.

\section{Change in Ownership}

In addition to the listing of shares on the NYSE, a second, highly significant action also occurred in late 1993: Deutsche Bank agreed to reduce its ownership of Daimler-Benz from roughly thirty percent to less than twenty-five percent. $^{36}$ Even though the magnitude of the change was not large, it did signal to the market that large banks might have less influence on the company.

35. See DAimler-BenZ, 1997 Annual Report 3 (1998).

36. See Waller, supra note 13 , at 25. 
TABLE 1

DAIMLER-BENZ FINANCIAL PROFILE

\begin{tabular}{|c|c|c|c|c|c|c|c|c|c|c|c|c|}
\hline Period Ending & 1986 & 1987 & 1988 & 1989 & 1990 & 1991 & 1992 & 1993 & 1994 & 1995 & 1996 & 1997 \\
\hline Sales (DM millions) & 65.5 & 67.5 & 73.5 & 76.4 & 85.5 & 95.0 & 98.5 & 97.7 & 104.1 & 103.5 & 107.7 & 124.0 \\
\hline Net Income (DM millions) & 1.8 & 1.8 & 1.7 & 6.8 & 1.8 & 1.9 & 1.5 & 0.6 & 0.9 & -5.7 & 2.8 & 8.0 \\
\hline Return on Ending Equity (\%) & 15.9 & 18.4 & 15.7 & 41.4 & 10.4 & 10.3 & 7.6 & 2.2 & 4.4 & -41.4 & 10.5 & 22.9 \\
\hline Return on Beginning Equity (\%) & $\mathrm{N} / \mathrm{A}$ & 16.0 & 17.6 & 62.9 & 10.9 & 11.2 & 7.7 & 3.7 & 5.0 & -29.1 & 12.1 & 30.4 \\
\hline Net Worth: Total Assets (\%) & 26.4 & 20.8 & 20.8 & 26.2 & 25.6 & 24.9 & 22.2 & 19.5 & 21.0 & 15.1 & 23.5 & 25.6 \\
\hline Cash Flow: Total Revenues (\%) & 9.5 & 9.8 & 8.3 & 7.8 & 7.8 & 8.2 & 5.4 & 10.1 & 10.8 & 4.3 & 7.6 & 10.5 \\
\hline Revenues per Employee (DM) & 207.6 & 207.1 & 218.1 & 224.8 & 228.5 & 249.0 & 257.6 & 263.4 & 304.4 & 322.4 & 366.6 & 413.2 \\
\hline Total Employees (thousands) & 320.0 & 326.3 & 338.7 & 368.2 & 376.8 & 379.3 & 376.5 & 366.7 & 330.6 & 311.0 & 290.0 & 300.1 \\
\hline Employees in Germany (thousands) & 257.5 & 262.7 & 262.3 & 298.2 & 303.4 & 305.3 & 302.5 & 284.6 & 251.2 & 242.1 & 228.8 & 225.3 \\
\hline Market Capitalization ( $\$$ billions) & 26.9 & 15.7 & 17.7 & 22.3 & 17.1 & 22.8 & 15.5 & 22.6 & 25.3 & 26.1 & 35.4 & 35.2 \\
\hline
\end{tabular}


As noted, under the German system of corporate governance, banks play a vital role. This influence causes companies to over-invest, to borrow more than they need, and to diversify excessively. Further, bank influence hampers restructuring efforts that increase financial risk, such as borrowing funds or selling assets solely to pay dividends, or transactions that reduce the co-insurance effects of corporate diversification, such as launching spin-offs. Efficient corporate restructuring transactions are simply much less likely to occur in firms that are subject to communitarian corporate governance structures.

In January 1994, when Deutsche Bank announced that it would sell a large stake in Daimler-Benz, Daimler-Benz stock rose approximately thirteen percent higher than the market return for the month, no doubt in large measure due to this signal of reduced bank influence. ${ }^{37}$ With reduced bank ownership and the prospect of even less bank ownership in the future, the intrinsic value of listing on the NYSE is greatly enhanced. The liquidity of the NYSE and the transparency of U.S. accounting standards are valuable to investors. As Daimler-Benz becomes more oriented toward increasing shareholder value, the liquidity of the NYSE might be used to achieve such restructurings as mergers, spin-offs, or equity carve-outs. Finally, increased share liquidity and dispersed ownership also increases the firm's exposure to the disciplinary effects of the market for corporate control. That is, the easier it is for a potential raider to buy shares in a target company, the greater the discipline of the financial markets in keeping managers from dissipating corporate resources. Although this is unlikely to be a significant source of value in the Daimler-Benz case, there is still an improvement in the value of a share.

\section{Restructuring}

A third significant action occurred in mid-July 1995. The new chairman of the management board, Jurgen Schrempp, announced plans to embark on a major restructuring of the Daimler-Benz Aerospace Division. ${ }^{38}$ This announcement was followed by more specific announcements and actions, including walking away from Fokker Aircraft-of which Daimler-Benz owned fifty-one percent-in early 1996. This initial announcement was followed by many other announcements of asset sales or business closures in aerospace and in the electronics/diesel/railway system business, which was known as AEG Daimler-Benz Industries until 1996. ${ }^{39}$ At the time of the initial announcement, July 21, 1996, Daimler-Benz stock experienced an excess return of approximately two percent. ${ }^{40}$

The need for the restructuring grew over the period from 1986 to 1993, when Daimler-Benz increased its diversification significantly. Since then, it has

\footnotetext{
37. See Bloomberg Financial Markets, Historical Returns Database (May 1998).

38. See Brian Coleman, Daimler Aerospace Comes Down to Earth, WALl ST. J., July 21, 1995, at

39. See Daimler-Benz, supra note 14 , at 3.

40. See BlOOMBERG FinANCIAL MARKETS, supra note 37.
} A6. 
refocused and become more concentrated in its core business. Table 2 shows the revenue percentages generated by the different lines of business between 1986 and 1997. It also shows the percentage of revenue generated outside of Germany. Clearly, the company became more diversified internationally by 1997 than it had been before. This trend is beneficial because it limits the risk of real exchange rate changes. Consistent with the discussion in the Bradley et al. article, greater globalization of a firm's business is likely to lead to a greater reliance on contractarian forms of corporate governance. In the area of crossindustry diversification, it is evident that Daimler-Benz is concentrating its resources in areas where it arguably retains substantial comparative advantage. The percentage of revenues derived from automobiles has increased, as has the percentage of revenues from its service subsidiary. On the other hand, Daimler-Benz's interests in electrical and aerospace business have been reduced substantially.

In its 1996 Annual Report, the company specifically noted how it had overhauled its business portfolio:

What was once a broad assortment of 35 separate areas of commercial activity has now been trimmed and combined into 23 business units. This was mainly the result of eliminating businesses which could not meet requisite earnings and return targets or did not fit within the core activities. Highlights of this effort included:

(1) Withdrawal from Fokker's and Dornier's regional aircraft businesses;

(2) Disposition of the energy systems technology business;

(3) Disposition of the industrial automation business;

(4) Withdrawal from debis' marketing services activities; and

(5) Sale of the Group's recognition and sorting systems business. ${ }^{41}$

However, despite its wide and, perhaps with hindsight, ill-conceived diversification strategy, Daimler-Benz never suffered a serious conglomerate discount. Berger and Ofek show that conglomerate firms sell, on average, at substantial discounts to the aggregate stand-alone value of their components. ${ }^{42}$ Tables 3A and 3B show valuation metrics for Daimler-Benz compared to certain industrial averages. Specifically, the tables show its historical market price-to-book-value ratio and its historical market-price-to-cash-flow measures. Along with these measures are identical average metrics for the firms in the industries in which Daimler-Benz operates. If there had been a significant, obvious discount, it would appear as a linear combination of industry metrics weighted by Daimler-Benz Industry Weightings being greater than DaimlerBenz's own market-price-to-book-value and market-price-to-cash-flow measures. That is, the weighted average valuation metrics, such as market-to-book

41. DAimler-BenZ, 1996 ANNUAl RePORT 3 (1997) (format of numbered list differs from bulleted list in original; changes reflect journal conventions).

42. See Paul Berger \& Eli Ofek, Diversification's Effect on Firm Value, 37 J. FIn. ECON. 39, 39 (1995); see also Robert Comment \& Gregg Jarrell, Corporate Focus and Stock Returns, 37 J. FIN. ECON. 67, 67 (1995). 
TABLE 2

DAIMLER-BENZ DIVERSIFICATION

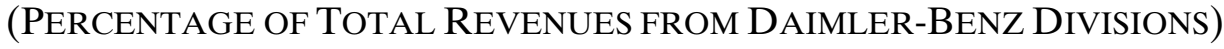

\begin{tabular}{|c|c|c|c|c|c|c|c|c|c|c|c|c|}
\hline & 1986 & 1987 & 1988 & 1989 & 1990 & 1991 & 1992 & 1993 & 1994 & 1995 & $1996^{*}$ & $1997 *$ \\
\hline Mercedes Benz & 75.0 & 75.4 & 74.7 & 71.9 & 67.7 & 68.7 & 65.8 & 63.1 & 65.6 & 66.4 & 69.4 & 70.5 \\
\hline $\begin{array}{l}\text { AEG Daimler-Benz } \\
\text { Industries/ Directly } \\
\text { Managed Businesses }\end{array}$ & 16.9 & 11.8 & 17.9 & 15.5 & 14.9 & 14.3 & 11.3 & 11.0 & 9.6 & 9.5 & 7.2 & 5.8 \\
\hline $\begin{array}{l}\text { Daimler-Benz } \\
\text { Aerospace }\end{array}$ & 7.4 & 6.5 & 6.8 & 9.8 & 14.2 & 12.6 & 17.0 & 18.6 & 16.4 & 14.4 & 11.7 & 11.7 \\
\hline Debis/Services & N/A & N/A & N/A & N/A & 3.2 & 4.4 & 5.9 & 7.3 & 8.4 & 9.6 & 11.7 & 11.8 \\
\hline Foreign Revenue & 57.5 & 58.4 & 60.4 & 61.3 & 57.1 & 53.2 & 56.8 & 60.8 & 62.5 & 63.2 & 63.0 & 66.9 \\
\hline
\end{tabular}


and price-to-cash-flow, would exceed those same metrics for the conglomerate, Daimler-Benz. For the years before 1993, Daimler-Benz's valuation metrics roughly approximated those of its reference group. For later years, DaimlerBenz had higher valuation parameters than any of its component industries. The data suggest that the relative market valuation of the company's core businesses improved as a result of the refocusing of its business mix. We attribute this result to the increased attention to shareholder value and the movement toward the contractarian corporate governance system.

TABLE 3A

CONGLOMERATE VALUATION PARAMETERS:

MARKET PRICE TO BOOK VALUE

\begin{tabular}{lccccccc}
\hline Index or Company Name & $1 / 93$ & $1 / 94$ & $1 / 95$ & $1 / 96$ & $1 / 97$ & $11 / 97$ & Average \\
\hline Automobile & 0.93 & 1.62 & 1.73 & 1.68 & 2.09 & 2.06 & 1.8 \\
Electrical \& Electronics & 1.97 & 2.28 & 2.19 & 2.62 & 2.72 & 3.24 & 2.1 \\
Financial Services & 1.48 & 1.86 & 1.66 & 2.18 & 2.34 & 2.85 & 2.1 \\
Aerospace \& Military & 1.22 & 1.80 & 1.86 & 2.74 & 3.64 & 3.69 & 2.7 \\
Technology & & & & & & & \\
Boeing & 1.69 & 1.82 & 1.78 & 2.75 & 3.40 & 3.80 & 2.6 \\
Daimler-Benz & 1.42 & 2.20 & 1.93 & 1.90 & 4.20 & 2.44 & 2.7 \\
\hline
\end{tabular}

Source: Morgan STANLEy CAPITAL InTERnATIONAL PERSPECTIVES (data taken from monthly issues, as indicated). These are industry averages except for the two named companies. 
TABLE 3B

CONGLOMERATE VALUATION PARAMETERS:

MARKET PRICE TO CASH FLOW

\begin{tabular}{|c|c|c|c|c|c|c|c|}
\hline Index or Company Name & $1 / 93$ & $1 / 94$ & $1 / 95$ & $1 / 96$ & $1 / 97$ & $11 / 97$ & Average \\
\hline Automobile & 4.8 & 6.5 & 6.5 & 5.6 & 6.9 & 6.6 & 6.3 \\
\hline Electrical \& Electronics & 7.2 & 9.3 & 8.2 & 9.7 & 12.3 & 11.5 & 9.9 \\
\hline Financial Services* & 24.5 & 21.2 & 16.3 & 23.3 & 19.0 & 24.7 & 21.1 \\
\hline $\begin{array}{l}\text { Aerospace \& Military } \\
\text { Technology }\end{array}$ & 5.5 & 7.4 & 9.3 & 12.4 & 15.0 & 11.7 & 10.7 \\
\hline Boeing & 5.5 & 6.5 & 7.9 & 13.9 & 20.7 & $\mathrm{~N} / \mathrm{A}$ & 11.78 \\
\hline Daimler-Benz & 3.2 & 4.6 & 5.5 & 6.2 & 31.8 & 8.7 & 14.1 \\
\hline Daimler-Benz* & 9.7 & 28.5 & Loss & 33.6 & Loss & & \\
\hline
\end{tabular}

*Price to Earnings

Source: Morgan Stanley CAPITAl InTERnAtional PersPectives (data taken from monthly issues, as indicated). These are industry averages except for the two named companies. 
TABLE 4A

COMPARATIVE VALUATION PARAMETERS:

MARKET PRICE TO BOOK VALUE

\begin{tabular}{|c|c|c|c|c|c|c|c|c|c|c|c|}
\hline & D.-B. & BMW & Porsche & VW & Chrysler & Ford & GM & Honda & Nissan & Toyota & Volvo \\
\hline 1986 & 5.26 & 3.52 & 3.35 & 1.42 & 1.33 & 1.29 & 0.72 & 1.63 & 0.69 & 2.22 & 1.57 \\
\hline 1987 & 2.52 & 2.55 & 1.27 & 0.73 & 0.90 & 1.36 & 0.64 & 1.58 & 1.18 & 1.61 & 1.01 \\
\hline 1988 & 3.52 & 2.54 & 1.73 & 1.13 & 0.88 & 1.39 & 0.79 & 2.24 & 1.91 & 2.17 & 1.27 \\
\hline 1989 & 3.10 & 2.57 & 2.08 & 1.54 & 0.58 & 0.99 & 0.73 & 1.82 & 2.21 & 2.05 & 1.28 \\
\hline 1990 & 2.11 & 1.19 & 1.67 & 0.88 & 0.39 & 0.55 & 0.60 & 1.17 & 0.99 & 1.39 & 0.48 \\
\hline 1991 & 2.11 & 1.51 & 1.14 & 0.80 & 0.39 & 0.57 & 0.55 & 1.35 & 0.89 & 1.22 & 0.72 \\
\hline 1992 & 1.42 & 1.43 & 0.90 & 0.58 & 1.53 & 0.91 & 0.74 & 1.15 & 0.78 & 1.17 & 0.81 \\
\hline 1993 & 2.20 & 2.01 & 1.76 & 1.08 & 2.09 & 2.14 & 6.48 & 1.43 & 1.05 & 1.39 & 1.44 \\
\hline 1994 & 1.93 & 2.13 & 2.83 & 1.27 & 2.54 & 1.79 & 5.02 & 1.78 & 1.31 & 1.62 & 2.04 \\
\hline 1995 & 1.90 & 1.94 & 3.21 & 1.48 & 1.83 & 1.36 & 3.01 & 2.04 & 1.39 & 1.63 & 1.44 \\
\hline 1996 & 4.20 & 2.71 & 5.28 & 2.13 & 2.28 & 1.52 & 2.24 & 2.82 & 1.24 & 2.35 & 1.55 \\
\hline 1997 & 2.44 & 3.01 & 10.63 & 3.27 & 2.08 & 1.91 & 2.10 & 3.24 & 1.03 & 2.46 & 1.71 \\
\hline Average & 2.73 & 2.26 & 2.99 & 1.36 & 1.40 & 1.32 & 1.97 & 1.86 & 1.22 & 1.77 & 1.28 \\
\hline
\end{tabular}

Source: MORGAN STANLEY CAPITAL INTERNATIONAL PERSPECTIVES (multiple issues); STANDARD \& POOR's STOCK REPORTS (multiple reports). Results are based on data available as of January 1 of the following year. The 1997 results for BMW, Porsche, VW, Nissan, Toyota, and Volvo are based on data available on December 1, 1997. 
TABLE 4B

COMPARATIVE VALUATION PARAMETERS: MARKET PRICE TO CASH FLOW

\begin{tabular}{|c|c|c|c|c|c|c|c|c|c|c|c|}
\hline & D.-B. & BMW & Porsche & VW & Chrysler & Ford & GM & Honda & Nissan & Toyota & Volvo \\
\hline 1986 & 9.3 & 7.4 & 5.6 & 2.0 & 3.6 & 2.2 & 2.3 & 5.9 & N/A & 10.9 & 4.6 \\
\hline 1987 & 5.0 & 5.1 & 2.4 & 1.3 & 3.2 & 2.6 & 2.2 & 6.5 & N/A & 9.5 & 3.5 \\
\hline 1988 & 6.3 & 5.0 & 3.8 & 2.7 & 4.0 & 3.0 & 2.8 & 11.0 & N/A & 12.5 & 4.5 \\
\hline 1989 & 6.1 & 5.2 & 6.1 & 4.3 & 2.4 & 2.4 & 2.8 & 7.6 & 12.0 & 12.6 & 5.0 \\
\hline 1990 & 2.7 & 2.9 & 4.4 & 2.5 & 6.9 & 2.1 & 2.8 & 4.8 & 5.4 & 7.5 & 2.3 \\
\hline 1991 & 5.1 & 3.4 & 3.2 & 2.2 & Loss & 5.7 & Loss & 5.5 & 5.2 & 6.8 & 16.3 \\
\hline 1992 & 3.2 & 3.4 & 3.4 & 1.7 & 6.0 & 3.6 & 10.8 & 5.3 & 4.7 & 7.8 & 6.5 \\
\hline 1993 & 4.6 & 5.0 & 10.4 & 2.9 & 6.1 & 4.0 & 7.6 & 7.6 & 5.0 & 10.0 & Loss \\
\hline 1994 & 5.5 & 6.1 & Loss & 5.3 & 4.1 & 2.3 & 3.0 & 8.8 & 6.0 & 14.9 & 5.4 \\
\hline 1995 & 6.2 & 4.8 & 12.1 & 2.5 & 6.3 & 2.1 & 3.2 & 12.0 & 5.9 & 13.3 & 3.9 \\
\hline 1996 & 31.8 & 6.3 & 13.5 & 3.4 & 5.0 & 2.5 & 3.1 & 11.2 & 4.9 & 18.8 & 4.2 \\
\hline 1997 & 8.7 & 7.2 & 27.2 & 6.7 & 5.8 & 2.7 & 3.1 & 11.9 & 2.7 & 16.8 & 5.9 \\
\hline Average & 7.9 & 5.2 & 7.7 & 3.1 & 4.5 & 2.9 & 3.6 & 8.2 & 5.8 & 11.8 & 5.2 \\
\hline
\end{tabular}

Source: MORGAN STANLEY CAPITAL INTERNATIONAL PERSPECTIVES (multiple issues); STANDARD \& POOR'S STOCK REPORTS (multiple reports). Results are based on data available as of January 1 of the following year. The 1997 results for BMW, Porsche, VW, Nissan, Toyota, and Volvo are based on data available on December 1,1997. Losses are noted as "loss" and are computed as zero. 
Even though Daimler-Benz went through a period of diversifying from the automobile business, it continued to be highly valued relative to other automobile companies. Tables $4 \mathrm{~A}$ and $4 \mathrm{~B}$ show Daimler-Benz's value compared to other automobile firms. The non-German automobile companies have stock traded in the United States; therefore, their measures of book value and cash flow comply with U.S. GAAP. Except for Daimler-Benz, none of the German firms are traded in the United States; therefore, their book values and cash flows are reported according to German GAAP. Here, Daimler-Benz's data is reported using German GAAP; however, because its average valuation parameters exceeded those of its German counterparts, use of German GAAP does not cause extreme distortion. Between 1993 and 1997, Daimler-Benz had a higher market-price-to-book-value ratio and higher market-price-to-cashflow value than virtually all other automobile firms. Its average valuation parameters also exceeded those of other relevant automobile companies, except that its average market-price-to-cash-flow value was lower than that of Toyota.

Everything considered, Daimler-Benz's renewed focus on the automobile business and its willingness to shed poor performing, non-core businesses was a plus. Unfortunately, German governance and a comparatively illiquid German stock market limit the methods by which Daimler-Benz can dispose of its assets and use its proceeds compared to methods available in the United States. Because a bank dominates its supervisory board, it is unlikely that Daimler-Benz will ever do a complete spin-off of a division to existing shareholders. Similarly, a carve-out may be prevented, even though the firm would receive cash. The funds could be invested in activities that are riskier than the ones carved out or invested in core businesses, rather than in diversifying activities. Such action would place Daimler-Benz's debt in a riskier position than it currently is in. In addition, because of the low liquidity of the German stock markets, it is not clear whether divestiture of a division through a carve-out would ever yield higher proceeds than would a direct sale to another company. Nonetheless, in view of Daimler-Benz's limited options for divestiture, the company seems to be moving forward in refocusing itself.

\section{E. Incentive Compensation}

The fourth important action undertaken by Daimler-Benz was its adoption of a stock-oriented incentive compensation plan. This plan is quite a departure from customary practice in Germany. The company wrote in its 1996 Annual Report:

Daimler-Benz must also achieve its strategic goals in order to increase stockholder value. These objectives can in turn only be fulfilled if the Group's employees are properly incentivized through a performance oriented compensation system and participation in the group's success. Recognizing the need for prompt action, the Board of Management proposed adoption of a stock option plan at the 1996 annual general meeting of stockholders. At this year's annual general meeting, the Board of Man- 
agement will seek authorization to increase the capital dedicated to the plan. Participation in the plan will then be extended to additional levels of management.

Not only has the company adopted a stock option plan, but it also has implemented a bonus plan that depends on the actual level of dividends exceeding a specified target. ${ }^{44}$ This plan may conflict with the stock-option initiative because it encourages the company to distribute cash, whereas the stock price is enhanced through retention of earnings. Nonetheless, these are new incentives not to hoard cash. Given the incentives to retain excess funds to fund negative net present value projects, we interpret this part of the new compensation plan as an effort to manage the firm's communitarian investment incentive.

Daimler-Benz management compensation has reflected the company's success. In 1995, when Daimler-Benz lost money, total remuneration to the managing and supervisory boards was DM 12.5 million. In 1996, when the company returned to profitability, total cash remuneration to its boards, which remained the same size as before, was DM 25.5 million. Remunerations-salary plus bonus-more than doubled in response to improved corporate performance. ${ }^{45}$

The supervisory board is now remunerated based on the difference between actual dividends paid and a specified threshold level. ${ }^{46}$ For 1997, ninety-three percent of the remuneration paid to supervisory board members as a group was paid as a result of this arrangement. ${ }^{47}$ The incentive compensation scheme for the supervisory board accomplishes two objectives. First, it provides incentives for the board that are aligned with those of the shareholders' interests. Second, it reduces, and perhaps even eliminates, the firm's incentive to hoard cash or to over-invest. It motivates directors to give free cash flow to shareholders rather than invest in negative net present value opportunities.

\section{F. Security Price Performance}

Table 5 shows the performance of Daimler-Benz stock over various time periods. Before Daimler-Benz listed on the NYSE and began its restructuring activities, Daimler-Benz stock languished. For example, its compound annual total return in U.S. dollars from January 1, 1984, to February 29, 1996, was only eleven percent. ${ }^{48}$ This return contrasts with the total annual return of Standard and Poor's 500 ("S\&P 500") of 17.1\%. " From January 1990 to the end of 1997, its return was seven percent compared to $13.5 \%$ for the S\&P 500. Eliminating those early years, its performance roughly matches its global industry benchmark. Consequently, the performance of Daimler-Benz improved relative to

\footnotetext{
43. DAIMLER-BENZ, supra note 41 , at 4.

44. See Daimler-Benz, supra note 14, at 67.

45. See id.

46. See Daimler-Benz, supra note 16, at 64.

47. See id.

48. See DAIMLER-BENZ, supra note 35 , at 88 .

49. See BloOmberg FinANCIAL MARKETS, supra note 37.
} 
that of its industry peers and relative to that of the overall U.S. stock market as the firm transformed itself into a contractarian form of corporate governance.

TABLE 5

Daimler-BenZ: Percentage Total Annual Returns FOR SELECTED PERIODS

\begin{tabular}{lccc}
\hline & $\begin{array}{c}\text { Daimler-Benz } \\
\text { Returns }\end{array}$ & $\begin{array}{c}\text { S\&P 500 } \\
\text { Index }\end{array}$ & $\begin{array}{c}\text { S\&P } \\
\text { Auto Index }\end{array}$ \\
\hline 1/1/90-12/31/97 & 7.0 & 13.5 & 7.15 \\
$11 / 1 / 93-6 / 30 / 98$ & 22.6 & 23.6 & 21.70 \\
$1 / 1 / 95-6 / 30 / 98$ & 27.0 & 32.1 & 33.40 \\
$6 / 1 / 93-6 / 30 / 98$ & 37.0 & 30.8 & 39.80 \\
& & & \\
\hline Source: BLOOMBERG FinANCIAL MARKETS, HistORICAL RETURNS DATABASE (May 1998).
\end{tabular}

\section{G. The Chrysler Merger}

On May 7, 1998, Daimler-Benz announced it would merge with Chrysler in a stock transaction. ${ }^{50}$ The two companies are now known as DaimlerChrysler AG and have combined revenues of $\$ 130$ billion. ${ }^{51}$ Although investment bankers characterized the transaction as a merger of equals, Daimler-Benz effectively bought Chrysler for $\$ 38$ billion. $^{52}$ Between the close of the NYSE on May 6, 1998, and the close on May 8, 1998, Chrysler stock rose by $10.24 \%$, and Daimler-Benz stock rose by $2.59 \%{ }^{53}$ The S\&P 500 rose by only $.29 \%$ over the same period. ${ }_{55}^{54}$ The market obviously greeted this merger with great enthusiasm. $^{55}$

50. See Daimler, Chrysler Revise Swap Ratio in Auto Merger, BloOMBERG Fin. MARKeTS COMmOditiEs News, June 8, 1998, at 1.

51. See id.

52. See id.

53. See Comparative Returns May 6, 1998 to June 11, 1998, BLOOMBERG Fin. MARKETS COMmoditiEs NEws (Chrysler Corp., S\&P 500, S\&P Automobiles). Over the same period, the S\&P Auto Index increased by $2.89 \%$. This increase was slightly greater than the rise in Daimler-Benz stock. However, the S\&P Auto Index includes Chrysler, which had more than a $10 \%$ gain. Without Chrysler, Daimler-Benz would have risen more than the auto index. Both boards approved the merger before the end of May, shareholder votes for both companies were conducted in Sept. 1998, and the deal was approved, as expected. See id.

54. See id.

55. For example, Salomon Smith Barney was absolutely thrilled by the combination. See Salomon Smith Barney, supra note 27, at 83, 331. 
The exchange ratio was .6235 DaimlerChrysler share for each share of Chrysler held. ${ }^{56}$ Daimler-Benz holders received one share of DaimlerChrysler for each share held. After the deal closed, there were a little more than one billion shares outstanding. At the time of closing, Daimler-Benz's former shareholders owned roughly fifty-six percent of the combined company, and Chrysler's original shareholders owned roughly forty-four percent. ${ }^{57}$

Daimler-Benz estimated that sixty-three percent of its stock was held by German owners, and ten percent of its shareholders were in the United States. ${ }^{58}$ There is no comparable public data for Chrysler, but, if Chrysler's German ownership is comparable to Daimler-Benz's U.S. ownership, German ownership of the combined firm has been reduced to less than forty percent of the total. This, by itself, may be sufficient to keep the new firm from slipping back to Daimler-Benz's old communitarian ways. The preponderance of voting rights will not belong to German banks as it did, because all shares will carry the same voting rights. The merger may solidify DaimlerChrysler's commitment to focus on shareholder value creation. Indeed, one might even speculate that with a change of ownership of the combined entity, the company may eventually eliminate its dual headquarters-Stuttgart and Detroit-by leaving Stuttgart and re-incorporating in the United States or some other country, such as the United Kingdom, where the contractarian model of corporate governance prevails.

In a recent Fortune article that described the motivation for and the structure of the merger, Jurgen Schrempp, the CEO of Daimler-Benz, summarized his view of the company as follows:

We are fortunate in another area, too. We are registered on the New York Stock Exchange. We have started doing U.S. GAAP . . accounting, despite hefty criticism in Germany. And in the past two years, we have changed the criteria around the company to put it on a [more profit-oriented] American basis. You know that I am called Mr. Shareholder Value and not always in a very positive vein. I think we have changed Daimler-Benz-not in a totally Anglo-Saxon sense, because I think there are some great benefits in Germany, but I think we have moved in that direction. ${ }^{59}$

The CEO's comments are indicative of Daimler-Benz's favorable attitude toward a contractarian corporate governance system. The post-combination ownership structure of DaimlerChrysler AG moves the company further away from the communitarian corporate governance system.

Some further evidence on the strategic and financial consequences of retaining the communitarian corporate governance system is provided in another

56. See Daimler, Chrysler Revise Swap Ratio in Auto Merger, supra note 50, at 1.

57. See Chrysler Corp., supra note 29; Daimler-Benz in STANDARD \& POOR's STOCK RePORTS (July 2, 1996). At the time of the merger, Daimler-Benz had 513.7 million shares outstanding, and Chrysler had 645.5 million shares outstanding. After the merger, the total number of shares will be 513.7 million shares plus 0.6235 times 645.5 million shares, for a total of 916 million shares. Chrysler owners will own 402.3 shares of 916 million shares, or $44 \%$ of the total.

58. Data was taken from Daimler-Benz's website, which was posted before the merger in 1998. See Daimler-Benz (visited Sept. 15, 1998) <http://www.daimler-benz.com>.

59. Alex Taylor III, Gentlemen, Start Your Engines, FoRTUNE, June 8, 1998, at 138, 146. 
Fortune article entitled "Volkswagen's Big New Headache." 60 The article describes the impact of the Daimler-Benz and Chrysler merger on Volkswagen ("VW") as follows:

The biggest challenge VW may face is winning those who will fuel any global expansion-international investors. VW is an inward-looking company, $20 \%$ owned by the German state of Lower Saxony, whose minister sits on the board and whose first concern is protecting jobs. By contrast, Daimler was able to merge smoothly with Chrysler because it had become Germany's poster boy for shareholder value. Daimler was the first German company to list shares on the New York Stock Exchange and adopt U.S. accounting standards. Comparing VW with Daimler when it comes to wooing investors "is like chalk and cheese" says John Lawson at Salomon Smith Barney in London. "You are talking about a shareholder backwater on one hand, and on the other a company that is trying its best to drag its part of Germany into a more AngloSaxon culture." 61

Even before the merger was finalized, DaimlerChrysler announced plans for three billion dollars in cost savings to enhance share value. ${ }^{62}$ These savings will be accomplished by a contraction in employment at the newly combined firm. This plan is clear evidence of a shift in the mode of corporate governance from communitarian to contractarian.

The shares of DaimlerChrysler are now listed on the NYSE. They are not traded as ADRs; rather, real shares are traded. Moreover, the shares are registered, unlike the shares of most German companies, which are in bearer form. ${ }^{63}$ The company pays dividends, holds shareholder meetings, and conducts voting largely in accordance with German practices; these practices required some forbearance by the Securities and Exchange Commission ("SEC") and some changes by DaimlerChrysler. ${ }^{64}$ However, some adjustments have been made. For example, under German law, only shareholders who own shares on the date of the shareholder meetings can vote. ${ }^{65}$ However, DaimlerChrysler has agreed to conform to SEC rules that require ten days' notice of a record date and thirty days between the record and meeting dates. ${ }^{66}$ Similarly, DaimlerChrysler shareholders will vote in person at shareholder meetings without having to give three days' notice of intent to vote at the meeting. ${ }^{67}$

Changes such as these may not have a huge effect on the governance of DaimlerChrysler in the near future, but there certainly could be a long-term effect as DaimlerChrysler falls under the more intense scrutiny of U.S. institu-

60. Janet Guyon, Volkswagen's Big New Headache, FORTUnE, June 8, 1998, at 144, 144.

61. Id.

62. See Gregory L. White \& Brian Coleman, Chrysler Daimler Focus on Value of Stock, WALL ST. J., Sept. 21, 1998, at A3.

63. See U.S. Securities and Exchange Commission, Release No. 34-40597 (Int'l Series Release No. 1163), II 2 (Oct. 23, 1998) (File No. SR-NYSE-98-37).

64. See id.

65. See id. II 3.

66. See id. II 4.

67. See id. at II 5 . 
tional investors. ${ }^{68}$ The board's composition will surely be affected. Moreover, as American influence increases as a result of bringing so many senior Chrysler managers into the combined entity, and as the center of gravity of decisionmaking shifts in favor of the United States, the company may switch its corporate nationality from Germany to the United States.

We interpret the transaction itself, as well as the strategic impact of the transaction on competitors, as evidence that supports the movement toward the contractarian corporate governance system. It is not possible to know how successful the merged company will be, but it seems clear that investors and analysts view the deal favorably, that the principals involved attribute the ability to complete a stock-based transaction to Daimler-Benz's willingness to list its shares on the NYSE several years ago, and that other German firms in the same industry which continue to embrace the communitarian corporate governance system are now viewed as being at a distinct competitive disadvantage. Changes in the financial and product markets have indeed created a need for communitarian companies to become more contractarian; strategic advantage is attained by the company that first recognizes and understands that need.

\section{IV}

\section{CONCLUSION}

To compete in fiercely competitive global product markets, companies must have access to global capital markets. They need financial flexibility to move quickly and decisively when confronted with competitive challenges.

Daimler-Benz had been operating in a very protected environment. The German bank-dominated governance system in Germany did not require Daimler-Benz to maximize shareholder wealth. Rather, the supervisory board seemed content with achieving satisfactory financial performance and trying to meet the economic, political, and social goals of other stakeholdersdebtholders, employees, customers, and the state. However, the automobile business is one of the most intensely competitive businesses in the world. To compete effectively, companies such as Daimler-Benz need a tremendous amount of financial flexibility. To achieve this end, Daimler-Benz had to look outside of Germany for the means. To convince foreign investors that it was not simply raising capital so that it might continue to conform to German corporate governance standards, Daimler-Benz had to perform as does a company conscious of shareholder value. It restructured itself dramatically and took actions that were uncharacteristic of German firms, signaling to investors that Daimler-Benz was changing. Daimler-Benz made obvious and credible commitments to reorient itself in favor of shareholder value. The acquisition of

68. DaimlerChrysler may not be influenced by index fund managers. Surprisingly, although Chrysler was included in the Standard \& Poor's Stock Index, the new DaimlerChrysler will not be included because it is classified as a foreign company. 
Chrysler was the most recent step, with the new ownership structure and its potential for altering the composition of DaimlerChrysler's supervisory board.

Several other German companies have followed Daimler-Benz into a NYSE listing, two of which-Deutsche Telecom and Hoechst-are also multinational giants. As more German firms follow, this trend will hasten the demise of the communitarian form of corporate governance, at least in Germany. 


\section{APPENDIX}

TABLE A1: PANEL A

COMPARATIVE FINANCIAL DATA

LONG TERM DEBT/NET WORTH IN PERCENTAGES

\begin{tabular}{lrrrrrrr}
\hline & 1991 & 1992 & 1993 & 1994 & 1995 & 1996 & 1997 \\
\hline D.-B. & 25 & 25 & 28 & 46 & 32 & 57 & 19.3 \\
Chrysler & 245 & 178 & 1005 & 71 & 90 & 62 & 78.9 \\
Ford & 221 & 335 & 353 & 301 & 287 & 265 & 261.2 \\
GM & 157 & 685 & 605 & 292 & 157 & 170 & 237.1 \\
Honda & 55 & 55 & 63 & 58 & 57 & 49 & 52.6 \\
Nissan & 101 & 117 & 150 & 155 & 142 & 141 & N/A \\
Toyota & 32 & 33 & 36 & 35 & 37 & 36 & N/A \\
Volvo & 30 & 53 & 49 & 23 & 24 & 27 & 31.4 \\
\hline
\end{tabular}

Source: Auto \& Truck Industry, VAlue Line InVESTMENT SuRVEY 101-11 (Mar. 14, 1997); Chrysler Corp., in STANDARD \& POOR's STOCK REPORTS (Feb. 24, 1997 \& Feb. 25, 1998); Daimler-Benz $A G$, in STANDARD \& POOR's STOCK REPORTS (Feb. 11, 1997); Ford Motors, in STANDARD \& POOR's STOCK REPORTS (Feb. 3, 1997 \& Jan. 30, 1998); General Motors, in STANDARD \& POOR's STOCK REPORTS (Jan. 30, 1997); Honda Motor, in STANDARD \& POOR'S STOCK REPORTS (Mar. 28, 1997 \& Mar. 20, 1998); Nissan, in VALUE LinE INVESTMENT SURVEY 108 (Sept. 11, 1998); Toyota, in VALUE LINE InVESTMENT SuRVEY, 110 (Sept. 11, 1998); Volvo $A B$, in STANDARD \& PoOR's Stock Reports (Apr. 1, 1997). See also Table 1 note. 
TABLE A1: PANEL B

COMPARATIVE FINANCIAL DATA

Net Worth/Total Assets in PERCENTAGes

\begin{tabular}{lrrrrrrr}
\hline & 1991 & 1992 & 1993 & 1994 & 1995 & 1996 & 1997 \\
\hline D.-B. & 25.7 & 22.9 & 19.9 & 21.6 & 14.9 & 23.4 & 38.0 \\
Chrysler & 14.2 & 16.4 & 13.6 & 19.8 & 20.3 & 20.6 & 18.9 \\
Ford & 11.7 & 6.3 & 6.1 & 8.3 & 9.7 & 9.9 & 11.0 \\
GM & 14.2 & 0.7 & 0.6 & 4.6 & 1.4 & 10.3 & 7.6 \\
Honda & 36.8 & 34.9 & 34.7 & 33.1 & 33.7 & 32.5 & 33.0 \\
Nissan & N/A & N/A & N/A & N/A & N/A & N/A & N/A \\
Toyota & N/A & N/A & N/A & N/A & N/A & N/A & N/A \\
Volvo & 31.7 & 25.4 & 20.1 & 31.3 & 36.9 & 36.9 & 41.0 \\
\hline
\end{tabular}

Source: Chrysler Corp., in STANDARD \& POOR's STOCK REPORTS (Feb. 24, 1997 \& Feb. 25, 1997); Daimler-Benz AG, in STANDARD \& POOR's STOCK REPORTS (Feb. 11, 1997); Ford Motors, in STANDARD \& POOR'S STOCK REPORTS (Feb. 3, 1997 \& Jan. 30, 1998); General Motors, in STANDARD \& POOR's STOCK REPORTS (Jan. 30, 1997); Honda Motor, in STANDARD \& POOR's STOCK REPORTS (Mar. 28, 1997 \& Mar. 20, 1998); Nissan, in VAlue Line INVESTMENT SURVEY 108 (Sept. 11, 1998); Toyota, in VALUE LINE InVESTMENT SURVEY, 110 (Sept. 11, 1998); Volvo $A B$, in STANDARD \& PoOR's Stock Reports (Apr. 1, 1997). See also Table 1 note.

TABLE A1: PANEL C

COMPARATIVE FINANCIAL DATA

RETURN ON COMMON EQUITY IN PERCENTAGES

\begin{tabular}{lrrrrrrr}
\hline & 1991 & 1992 & 1993 & 1994 & 1995 & 1996 & 1997 \\
\hline D.-B. & 9.1 & 3.6 & N/A & 3.0 & N/A & 10.5 & 26.6 \\
Chrysler & N/A & 6.3 & 35.3 & 34.7 & 19.4 & 32.1 & 24.5 \\
Ford & N/A & N/A & 16.2 & 24.5 & 16.9 & 15.5 & 23.9 \\
GM & N/A & N/A & 44.1 & 44.1 & 29.7 & 18.5 & 32.4 \\
Honda & 5.9 & 3.7 & 2.5 & 4.8 & 6.2 & 15.0 & 16.2 \\
Nissan & 3.2 & N/A & N/A & N/A & N/A & 1.5 & 4.0 \\
Toyota & 9.4 & 5.0 & 3.7 & 2.6 & 4.8 & 7.0 & 7.5 \\
Volvo & 5.2 & N/A & N/A & 19.4 & 16.4 & 14.5 & 22.9 \\
\hline
\end{tabular}

Source: Auto \& Truck Industry, VAlue Line InVESTMENT SuRVEY 101-11 (Mar. 14, 1997). See also Table 1 note. The discrepancies between Value Line data and Daimler-Benz's 1997 Annual Report are a consequence of averaging and, for 1993, are explicable only if Value Line used income from operations instead of total net income. 